\title{
Un enfocament interactiu de la història de la física
}

\author{
Marta Pérez i López \\ IES Eugeni d'Ors, Vilafranca del Penedès \\ mpere3@xtec.cat
}

Aquest article presenta un material didàctic per aproximar-se a la història de la física seguint el fil conductor dels personatges i conceptes clau en la construcció d'aquesta ciència. Aquest material s'ha elaborat en forma de pàgina web.

Paraules clau: pàgina web, història de la ciència, història de la física, naturalesa de la ciència

\section{De la gènesi del treball...}

El material didàctic presentat en aquest article és el resultat del treball dut a terme durant el període d'una llicència retribuïda de modalitat B3 del curs 2006-2007 que duu per nom "Un enfocament interactiu de la història de la física” (fig. 1).

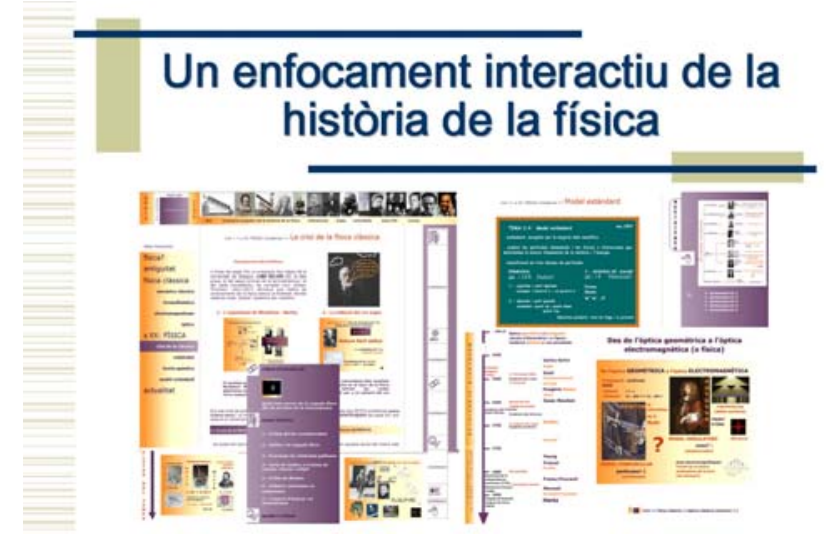

Figura 1. Una visió panoràmica dels continguts del web.

El material elaborat es presenta en forma de pàgina web (http://www.xtec.cat/ mpere3/) temàtica i interactiva -en la mesura dels recursos d'una persona novella- i es desenvolupa mitjançant un viatge per la història de la física a través d'alguns dels seus personatges més emblemàtics i de les seves principals contribucions científiques.
Aquests continguts es complementen amb una sèrie de recursos i activitats que en faciliten l'aproximació.

Però abans de continuar cal aclarir que no sóc especialista en història de la ciència, ni tan sols física de formació. Ara bé, durant una bona colla d'anys he impartit la física de batxillerat i sóc d'aquelles químiques que s'han deixat captivar per la seva bellesa en la mesura que, tot intentant ensenyar-ne, n'aprenia. I parlant de la bellesa, i fent memòria històrica, també sóc d'aquelles que durant els meus anys de formació a la universitat vaig sentir un enorme plaer quan, per primera vegada, vaig veure escrites a la pissarra les elegants equacions de Maxwell. Així mateix, la meva curiositat envers els personatges probablement ja es remunta als meus anys de BUP; en efecte, aquell llibre de $3 r$, l'Spin de la Vicens Vives, començava amb una imatge i una breu ressenya biogràfica dels personatges clau que em cridà immediatament l'atenció.

Quant al meu interès per l'epistemologia i per la història de la ciència també hi té a veure, sens dubte, el fet d'haver cursat el CAP l'any 1989 de la mà del Dr. Aureli Caamaño, qui ens va proporcionar una bona formació en un moment en què la didàctica de les ciències era més sensible a la incorporació d'aquests aspectes al currículum.

D'altra banda en els darrers anys, mentre constatava no sense certa angoixa una davallada en l'interès per la disciplina, vaig creure interessant d'explorar el potencial didàctic de les TIC. Aleshores, vaig decidir millorar la meva formació en informàtica. 
Fruit d'aquestes motivacions, durant el curs 2005-2006, vaig presentar com a projecte final del curs telemàtic "Disseny i creació de pàgines web" una primera versió de la pàgina web que portava per títol "Una breu història de les grans teories".

La meva pretensió inicial era elaborar una pàgina web de l'assignatura (incorporant-hi les programacions, exàmens, enllaços útils...) que em permetés apropar-me més al món dels meus alumnes per tal de motivar-los i també d'harmonitzar els seus interessos amb els meus.

Estructurada de manera semblant a la versió actual, en la pàgina d'inici feia una declaració d'intencions del contingut a elaborar tot plantejant qüestions com les següents: "Quines són les grans teories que han edificat el cos de coneixement de les ciències físiques? Com varen sorgir? Quines en són les aplicacions tecnològiques? Quina va ser l'evolució de les idees? Quins són els personatges clau que les van desenvolupar? Quines són les més rellevants relacions ciència - tecnologia - societat que se'n deriven?"

En un altre ordre de coses una bona raó que em va animar a presentar-ho com a projecte de llicència va ser el fet de detectar la mancança de materials interactius adreçats a secundària que incorporessin la història de la ciència i de la tècnica.

Amb tot aquest treball previ i sota la remarcable supervisió conceptual i tutelar del Dr. Albert Bramon, s'ha elaborat aquesta primera aproximació al projecte inicial.

\section{Objectius del treball}

Aquest treball pretén:

- Aportar un material didàctic complementari i adequat per assolir alguns dels objectius curriculars de Física de més dimensió metacientífica, sovint considerats "secundaris" en els materials habituals; en especial, a components curriculars del tipus històric (les grans preguntes sobre el món, l'evolució dels conceptes i teories, les crisis, els personatges clau...), epistemològic (sobre la naturalesa de la ciència i del seu mètode...) i sociològic (les relacions CTS, la ciència com a creació col-lectiva, el paper de les controvèrsies...).

- Potenciar una visió més humanista de la física que contribueixi a afavorir l'actitud i l'interès de l'alumnat envers el seu aprenentatge i envers el paper de la ciència i de la tècnica en el context de la cultura general de la Humanitat.

- Aprofitar el potencial didàctic i educatiu de les TIC, tant des del vessant metodològic, que afa- voreix un aprenentatge interactiu, comunicatiu, autònom i significatiu, com des del vessant informatiu que permet generar, organitzar i seleccionar recursos de la xarxa.

La idoneïtat d'aquest plantejament, a més, ve avalada, com assenyalà el Dr. Pere Grapí, pel fet que la matèria de Ciències de la Naturalesa de l'Educació Secundària Obligatòria té com a objectiu núm. 10 el desenvolupament de la capacitat de "reconèixer la naturalesa de la ciència $i$ situar els coneixements científics més importants en un context històric, per comprendre tant la gènesi dels conceptes $i$ teories fonamentals com les interaccions entre la ciència, la tecnologia i la societat" (DOGC núm. 4915 del 29.06.2007 pàg. 21901).

Seguint amb aquest argument, podem també afegir que en la versió provisional del currículum de física de batxillerat (febrer 2008), s'inclou com a competència específica de la matèria, "la competència en la comprensió de la naturalesa de la ciència". Aquesta competència "suposa que l'alumnat ha de desenvolupar alhora una comprensió epistemològica de la naturalesa de la ciència i de la construcció del coneixement científic".

D'altra banda en el mateix document s'especifica la contribució de la matèria a les competències generals del batxillerat i, concretament la darrera, la "competència en el coneixement $i$ interacció amb el món", finalitza amb la frase "la comprensió de la contribució que, al llarg de la història, la física ha fet a l'explicació del món i la manera com ha influitt en la cultura i el pensament".

\section{El web: estructura i organització dels materials}

Els continguts principals del web -menú verticals'estructuren seguint com a fil conductor la lògica formal de la pròpia disciplina, atès que la física és la més estructurada de les disciplines científiques i ho permet amb molta facilitat i claredat.

Des d'aquest criteri, la física clàssica i la física moderna (s. $X X)$, en són els eixos temàtics fonamentals (figura 2). Complementen aquests eixos centrals els apartats "física?", "antiguitat" i "actualitat". D'altra banda, s'hi inclou un menú horitzontal on es recullen altres utilitats.

Tot i que no és un enfocament correcte des del punt de vista historiogràfic, s'ha optat per aquesta alternativa perquè es valora que té més avantatges didàctics en relació als destinataris finals. De tota manera, els continguts principals del web -de les seccions que estan completes- s'estructuren en línies de temps: els científics més importants (que 
"son todos los que están, pero no están todos los que son") sí que s'han situat contextualitzats en el seu moment sociohistòric particular.

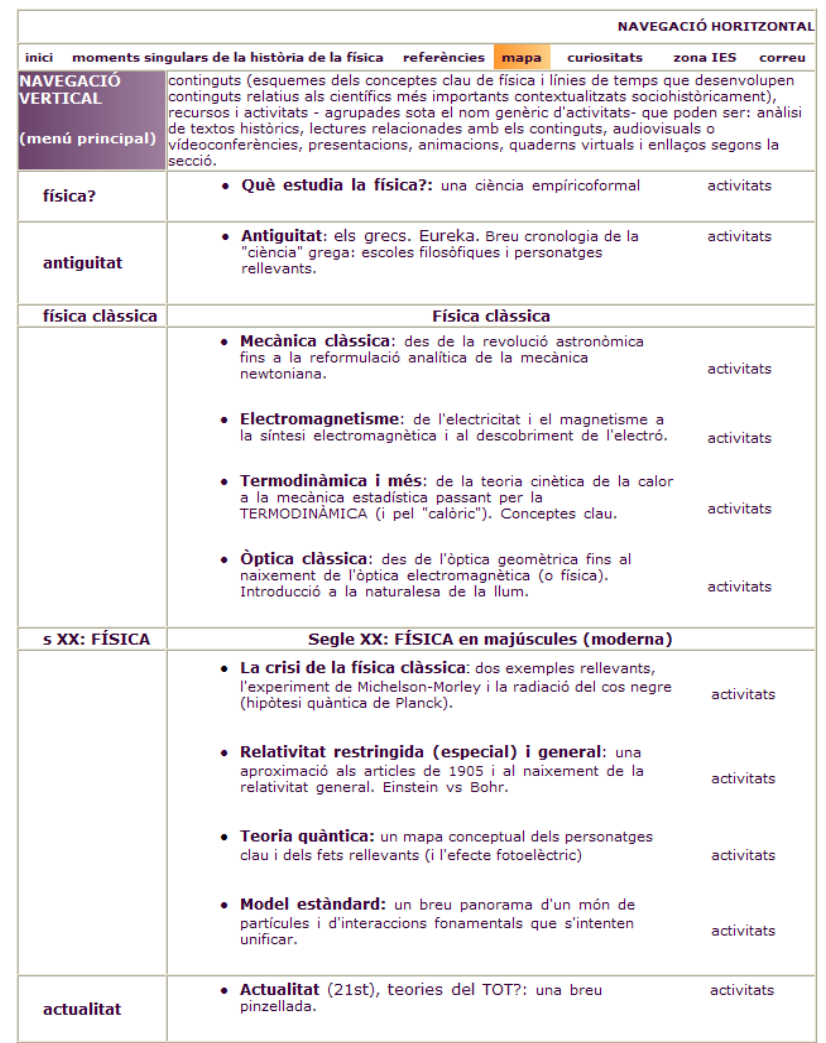

Figura 2. Mapa del web.
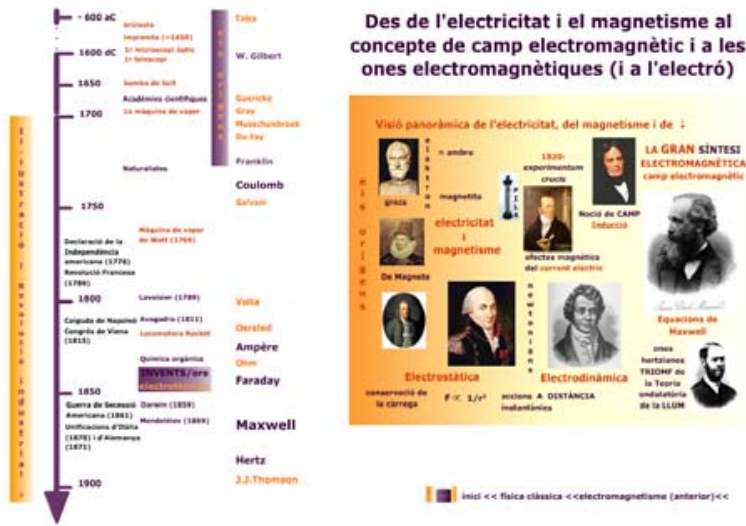

Figura 3. Exemple de línia de temps.

\section{Tot navegant pel web...}

Els materials i recursos que s'integren en el web es poden classificar en els següents tipus:
- biografies (vida, estudis i principals contribucions científiques) contextualitzades sociohistòricament mitjançant línies de temps (figura 3)

- animacions, simulacions o applets que il-lustren o amplien continguts

- vídeos i videoconferències

- presentacions

- referències textuals i virtuals

En aquests materials i recursos s'ha intentat reflectir els següents aspectes: els personatges emblemàtics, els conceptes clau, l'evolució d'algunes idees, conceptes i teories, certs experiments històrics, algunes crisis i controvèrsies, aportacions sobre la natura de la ciència i del seu mètode, algunes aplicacions tecnològiques $\mathrm{i}$ algunes relacions CTS significatives en la història.

D'altra banda s'hi ha incorporat també un conjunt d'activitats (figura 4), relatives als continguts, que es poden agrupar de la següent manera:

- alguns textos històrics o lectures representatives acompanyades de propostes de qüestions

- alguns qüestionaris interactius (Quaderns Virtuals)

- explora tu mateix!: enllaços a pàgines web relacionades.

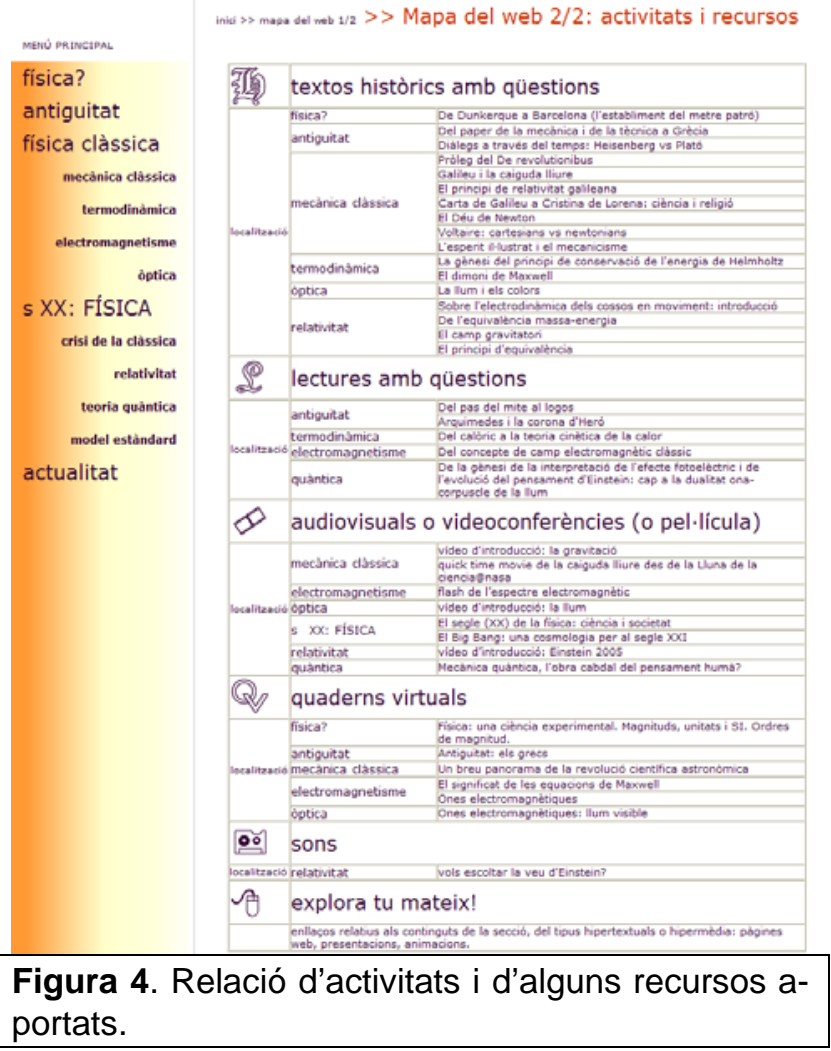




\section{I per acabar...}

Malgrat que per part nostra resta pendent la posada en pràctica d'aquest material, com que està disponible en un entorn virtual, podria utilitzar-se en diferents contextos educatius:

- autoaprenentatge complementari a la docència presencial de la física de Batxillerat

- utilització guiada a l'aula telemàtica per desenvolupar crèdits variables interdisciplinaris d'història de la ciència o CTS

- utilització puntual dels textos històrics i les lectures a l'aula ordinària

- pot ser un recurs informatiu i formatiu per al professorat que imparteix física o ciències de la naturalesa, o que, simplement, s'interessa pel tema
- pot ser un recurs útil per a l'alumnat que faci algun treball de recerca relacionat amb els continguts desenvolupats en el web.

Val a dir també que el material aportat, atesa l'amplitud de la temàtica i els ambiciosos objectius inicials, és inevitablement incomplet i millorable. En aquest sentit requeriria una dedicació de temps que resulta poc compatible amb la nostra professió. De tota manera, com a mínim pot ser un petit reflex dels objectius inicials.

En darrer terme aquest treball pot constituir un punt de partida per aprofundir en els diversos àmbits que s'interrelacionen directament amb el món de la física i de la tecnologia i en el potencial didàctic de les TIC en el camp de l'educació. 